\title{
Climate change vulnerability and adaptation in resource dependent communities: a case study from West Greenland
}

\author{
James D. Ford*, Christina Goldhar \\ Department of Geography, McGill University, Montreal, Quebec H3A 0B9, Canada
}

\begin{abstract}
This paper reports on a project conducted over 4 field seasons in the town of Qeqertarsuaq in West Greenland, identifying and examining vulnerability and adaptation to climate change. Drawing upon semi-structured interviews with community members $(\mathrm{n}=132)$, key informant interviews with policy makers $(\mathrm{n}=10)$, and analysis of secondary sources, we documented changes in sea ice regimes, temperatures, and wind. Vulnerabilities to these changes are primarily associated with hunting and fishing. Constrained access and availability of key wildlife resources and increased harvesting dangers are affecting individuals and households closely linked to the subsistence economy. Adaptations that are being employed combine both reactive and anticipatory interventions autonomously undertaken at an individual and household level, including traveling to new fishing grounds, seeking alternative sources of income when harvesting activities are not possible, preparing for the unexpected, and an increased reliance on boat transport. The role of women in supporting male hunters/fishers, knowledge of environmental conditions, the existence of alternative sources of income, diversity and flexibility in harvesting, and willingness to alter livelihoods, are important factors that underpin adaptive capacity. Institutional constraints, however, are a major impediment to adaptation and have reduced the flexibility which has enabled historic adaptation to changing conditions. While alternative income sources are increasingly important in light of recent stresses, occupational hunters face restrictions on money-earning from non-harvesting activities, and various harvesting quotas fail to reflect recent alterations in species availability with changing climatic conditions. More broadly, hunting regulations have contributed to the erosion of the moral economy of harvesting and have weakened social networks, increasing vulnerability to projected future changes in climate.
\end{abstract}

KEY WORDS: Climate change - Vulnerability - Adaptation - Greenland · Disko Bay · Qeqertarsuaq · Inuit · Fishing $\cdot$ Hunting $\cdot$ Indigenous

\section{INTRODUCTION}

Greenland's climate is highly variable and strongly influenced by the North Atlantic Oscillation (NAO) and volcanic activity (Comiso 2003, Chylek et al. 2006, Box et al. 2009). This variability has allowed researchers to examine climate sensitivities in biophysical systems (Hamilton 2003, Hansen et al. 2003, Arnason 2007, Johannessen \& Miles 2011), which has gained increasing importance in light of projected ac- celerated warming over Greenland with anthropogenic climate change. Average temperatures, for instance, are projected to increase at a rate 1.2 to 3 times faster over Greenland than the global average in the 21st century (IPCC 2007). Climate warming will have consequences for Greenland's largely Inuit population: rising sea levels will increase coastal erosion, melting permafrost will affect infrastructure stability, reduced sea ice thickness and coverage will impact traditional subsistence activities, and warming 
coastal waters will affect the population health and spatial distribution of commercially harvested wildlife species (ACIA 2005, Drinkwater 2005, Hovelsrud et al. 2008, Holm 2010, Johannessen \& Miles 2011). Potential benefits have also been identified, including enhanced opportunities for resource development and exploitation of hydrological resources as the ice cap recedes, improved shipping, and new opportunities for fisheries (e.g. Atlantic cod, shrimp, char). These opportunities are being promoted by the Home Role Government (HRG), opening Greenland further to industrial development in hope of working towards eventual financial independence from Denmark (Wieland 2004, Arnason 2007, Nuttall 2008, 2009).

While the biophysical aspects of climate change in Greenland have been widely examined, human dimensions of climate change (HDCC) research examining vulnerability and adaptation is in its infancy (Ford \& Furgal 2009, Nuttall 2009, Holm 2010). Greenlandic HDCC scholarship has primarily focused on documenting indigenous observations of climate change and examining potential impacts. Thus, Holm (2010) documents observations of changing climatic conditions based on expert interviews in 23 communities, Nuttall $(2008,2009)$ examines broader implications of climate change for socio-economic development, and Van Voorst (2009) uses a community case study to examine social impacts. Others have focused on the human implications of past climatic variability -including the disappearance of the Norse in the 14th and 15th century and shifts in fisheries from cod to shrimp in the 20th century - using historical reconstructions to identify potential impacts of future climate change, and demonstrating significant adaptability and the role of non-climatic stresses in affecting human-environment relations (Vibe 1967, Hamilton et al. 2003, Dugmore et al. 2007, Huntington et al. 2007, Sejersen 2009, Sorensen 2010). These temporal analogue based studies provide important insights for understanding potential future impacts of climate change, but our overall knowledge on the nature and determinants of vulnerability and adaptation is constrained by the limited geographic coverage of existing research and absence of work examining how contemporary communities are experiencing and responding to changing conditions. Moreover, there is limited scholarship examining how socioeconomic transformations that have affected Greenland will determine vulnerability outcomes.

This study sought to reduce this deficit in understanding, reporting on a project undertaken over 4 field seasons in collaboration with the town of Qeqertarsuaq in West Greenland, which aimed to identify and examine vulnerability to climate change. The research was structured using a vulnerability approach, and incorporates mixed methods to develop a baseline understanding of how climatic risks and change are currently experienced and responded to, focusing primarily on the culturally and economically important subsistence-based economy (i.e. hunting, fishing). The local focus contrasts the political discourse on climate change in Greenland, where national interests have been prioritized over local issues, and small subsistence-based communities have been largely overlooked (Sejersen 2009). Yet while the findings are specific to Qeqertarsuaq, the work is indicative of some of the broader challenges and opportunities facing small Greenlandic communities that depend on hunting and fishing in a future that will be characterized by rapid climatic change.

\section{A VULNERABILITY-BASED APPROACH}

\subsection{Conceptual and methodological framing}

This study uses the approach of Ford \& Smit (2004) and Ford et al. (2006) - developed in an Arctic context and consistent with 'contextual' or 'type II' vulnerability assessments (Fussel \& Klein 2006, O'Brien et al. 2007, Keskitalo 2008) - to identify and characterize vulnerability. Vulnerability is a measure of the susceptibility to harm in a system in response to a stimulus or stimuli, and is a function of exposure and sensitivity to climate change and adaptive capacity (Smit \& Wandel 2006). The recognition of the role of adaptive capacity and sensitivity focuses vulnerability studies on the role and importance of non-climatic factors in amplifying or attenuating vulnerability alongside the nature of the climatic exposure (Smit et al. 2000, Smit \& Pilifosova 2003, Ford et al. 2010b). These determinants are influenced by social, economic, cultural, and political conditions and processes operating at multiple scales over time and space. Change in these non-climatic conditions plays an important role in determining vulnerability to climate change (Turner et al. 2003a, Keskitalo 2008, Westerhoff \& Smit 2009, Keskitalo et al. 2011).

Empirical application of this model has typically followed procedures outlined by Smit \& Pilifosova (2003), Ford \& Smit (2004), and Burton \& Lim (2005), beginning with the identification of current vulnerabilities, which provides the basis for examining future vulnerability under conditions of climate change. Few studies, however, have assessed both current and future vulnerability given the scope of 
the task, with most research (including the work reported here) focusing on current vulnerabilities. However, examining current vulnerability is important for understanding how climatic variability, change, and extremes are experienced and responded to, and for identifying pathways through which climate affects society, thereby empirically grounding assessments of future vulnerability (Duerden 2004, Fussel \& Klein 2006, Ford et al. 2010a, Malone \& Engle 2011).

Case studies have been widely used to document the nature and determinants of current vulnerability, involving close collaboration with communities and stakeholders necessary for effective actionorientated research (Turner et al. 2003b, Pearce et al. 2009, Ford et al. 2010a, Pearce 2011). Interviews have been the primary mechanism for data collection, both in the Arctic and more generally. Typically, interviews have focused on getting participants to recount risks they have experienced, to explain the effects that resulting stresses have, to describe adaptations, to identify challenges to adapting, as well as to offer broader insights on their livelihoods, thus shedding more light on the climate vulnerability context (Ford \& Pearce 2012). This has resulted in a wealth of information necessary for characterizing vulnerability, yet some scholars have critiqued the overreliance in many assessments on what informants say or report as opposed to what they do, the lack of long term studies, and reliance on limited data sources (Collings 2009, 2011, Huntington 2011, Ford \& Pearce 2012). With this in mind, this study used multiple methods and repeated fieldtrips, con-

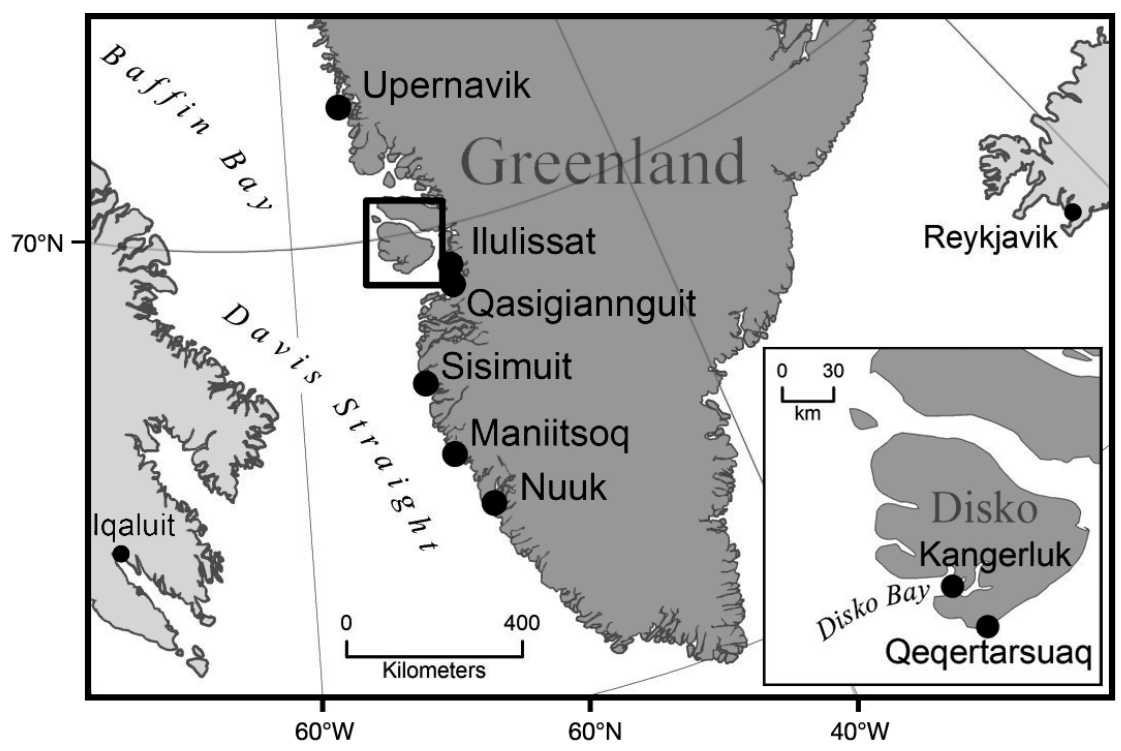

Fig. 1. Study settlement: Qeqertarsuaq, Qaasuitsup, Greenland sulted a large number of stakeholders, and continually examined and re-examined interpretations of vulnerability through triangulation and phased assertion techniques.

\subsection{Qeqertarsuaq case study}

The town of Qeqertarsuaq is located in the municipality of Qaasuitsup on Disko Island off the west coast of Greenland (Fig. 1). Qeqertarsuaq has a population of 907 , of which $90 \%$ are Kalaallit (Greenlandic Inuit), and neighbours Kangerluk, a small settlement with a population of 33 (Qaasuitsup Municipality 2010). The primary language is the West Greenlandic dialect of Kalaallisut (Greenlandic), with Danish comprising the second language of many residents.

The town has a mixed subsistence-cash economy composed of subsistence hunters and fishers as well as waged employment. Qeqertarsuaq's waged economy is based on commercial fishing, seafood processing, public administration, tourism, and seasonal labor. Public employment makes up an important part of the economy and is primarily provided by the Royal Greenland Company, which owns the local fish processing plant employing seasonal workers, and the local municipality. Unemployment was $2.4 \%$ in 2007 and average household income was 219082 Dkr (\$39000 US) in 2006, partly reflective of the success of the commercial fishery, highly dependent on shrimp and snowcrabs (Goldhar \& Ford 2010).

Locally harvested animals, known as kalaalimernit or 'Greenlandic' foods, are widely consumed and are a highly valued component of the local diet (Goldhar et al. 2010). The majority of these foods are marine species as Disko Bay is rich in shrimp, many fish and whale species. Typical animals consumed include harp seal (aataaq) Pagophilus groenlandicus, narwhal (qilalugaq) Monodon monoceros, minke whale (tilaagullik) Balaenoptera acutorostrata, reindeer (tutu) Rangifer tarandus, eider duck (miteq) Somateria mollissima, Greenland cod (saarullik) Gadus ogac, Arctic char (eqaluk) Salvelinus alpinus and Greenland halibut (qaleralik) Reinhardtius hippoglossoides. In the Survey of Living Conditions of the Arctic (Poppel et al. 2007), 45\% of Qeqertarsuaq households reported participating in hunting and fishing while sur- 
veys by Goldhar et al. (2010) document that $66 \%$ obtain at least half of their food from traditional sources.

Hunting and fishing are tightly regulated in Greenland, with 2 legally defined categories of hunters forming the basis of the licensing system: occupational and non-occupational hunters. In May 2008 there were 46 occupational and 150 non-occupational hunters in Qeqertarsuaq. Applicants have to meet specific criteria to obtain an occupational hunting license, harvesting a minimum portion of their food, in addition to meeting income criteria. Concerning fishing, there are 3 different types of licences available: temporary licences with an upper limit for the allowable catch, temporary licences without an upper limit, and permanent licences with an upper limit. Once the total allowable catch is determined for a regulated species, a quota may be allocated for in-shore fishing, off-shore fishing (also identified as coastal and ocean fishing), or for both. In-shore fishing takes place from small vessels below 75 gross registered tons (GRT)/ 120 gross tons (GT) and within a limit of 3 nautical miles (n miles) from shore. Off-shore vessels are over 75 GRT/120 GT, and compete with international fishing fleets, fishing on the open sea outside the $3 \mathrm{n}$ mile limit. There is also a subsistence fishery where residents are allowed to fish for personal consumption without a licence, but are not permitted to sell their catch. Licensing has important implications as species access and dispossession rights are differentiated by license sub-groups (Table 1). For example, nonoccupational hunters are restricted from harvesting certain species, are often allocated smaller quotas, and are restricted from selling their catch at the local outdoor market (kalaalimineerniarfik).

\subsection{Methods}

This research was undertaken in collaboration with community members in Qeqertarsuaq who were involved in setting the research questions, study design, data collection and interpretation, and dissemination of results. Given our interest in how climate-related conditions and change interact with the community, methods that facilitated in-depth interactions with participants over time and involving repeat visits were favoured. Fieldwork spanned $4 \mathrm{yr}$ with semi-structured interviews comprising the primary means of data collection. A targeted interview sample was conducted including members of the hunting and fishing community, women, and elders. Over this period, 4 field visits were conducted and ranged from roughly 2 to $>6 \mathrm{wk}$ in time. Interviews
Table 1. Licence requirements and hunting season dates for regulated animals in Qaasuitsup municipality. Hunting all other animals (including musk ox and reindeer) is presently not regulated. Hunting blue, sei, humpback and sperm whales is prohibited

\begin{tabular}{|c|c|}
\hline $\begin{array}{l}\text { Licence required } \\
\text { Animal }\end{array}$ & Hunting season dates \\
\hline \multicolumn{2}{|l|}{ Occupational } \\
\hline Minke whale & Apr 1 to Dec 31 \\
\hline Fin whale & Open \\
\hline Bowhead whale & Apr 1 to Dec 31 \\
\hline Walrus & Mar 1 to Apr 30 \\
\hline Polar bear & Sep 1 to Jun 30 \\
\hline \multicolumn{2}{|c|}{ Occupational and non-occupational } \\
\hline Small cetaceans ${ }^{a}$ & Open \\
\hline Seals & Open \\
\hline Arctic fox & Sep 16 to May 14 \\
\hline Arctic hare & Aug 1 to Apr 30 \\
\hline $\begin{array}{l}\text { Common guillemot, } \\
\text { Brünnich's guillemot }\end{array}$ & Sep 1 to Feb 28 \\
\hline Common eider & Oct 15 to Mar 31 \\
\hline King eider & Oct 15 to Feb 28 \\
\hline Cormorant & Sep 9 to Mar 31 \\
\hline Great northern diver & Sep 9 to Oct 15 \\
\hline Fulmar & Sep 1 to Oct 31 \\
\hline Little auk & Sep 1 to Apr 30 \\
\hline \multicolumn{2}{|c|}{$\begin{array}{l}\text { aE.g. narwhal, beluga, harbour porpoise, northern bottle- } \\
\text { nose whale, Atlantic white-sided dolphin, white-beaked } \\
\text { dolphin, long-finned pilot whale, and killer whale }\end{array}$} \\
\hline
\end{tabular}

ranged in duration from $\sim 30 \mathrm{~min}$ to $>2 \mathrm{~h}$ and were loosely structured around a number of key themes. Interview themes aimed to (1) identify climaterelated risks and changes that people have to deal with; (2) provide insights into how these risks are experienced and managed; and (3) identify the processes and conditions that have determined the availability, efficacy, and success of past and present adaptations. Around $10 \%$ of the community were interviewed (132 interviews) primarily in Greenlandic (Table 2). All interviews were simultaneously

Table 2. Demographic characteristics of the sample and the target population in Qeqertarsuaq. Statistics Greenland (2010)

\begin{tabular}{|lcc|}
\hline Variable & $\begin{array}{c}\text { Target population } \\
\mathrm{n}(\%)\end{array}$ & $\begin{array}{c}\text { Sample } \\
\mathrm{n}(\%)\end{array}$ \\
\hline Sex $(\mathrm{n}=132)$ & $375(51)$ & $72(55)$ \\
Male & $356(49)$ & $60(45)$ \\
Female & & \\
Age (yr) $(\mathrm{n}=115)^{\mathrm{a}}$ & $190(26)$ & $18(16)$ \\
$18-34$ & $333(45)$ & $44(38)$ \\
$35-54$ & $208(28)$ & \\
$55+$ & & \\
a17 participants did not provide their age & \\
\hline
\end{tabular}


translated by a member of the research team from the community. Recognizing the prevalence of global discourse on climate change introduced to Arctic communities through the media, we avoided framing the work as a 'climate change' project in order to avoid bias, instead emphasizing our interest in human-environment interactions. Additionally, 10 key informant interviews were conducted with those in local decision-making roles (such as the mayor and town personnel), businesses (e.g. fish plant, tourist operators), as well as policy makers in the capital of Nuuk, to obtain multiple perspectives on climaterelated risks, responses, and adaptation challenges.

In addition to the interviews, the research team spent considerable time in the community, engaging in daily activities including fishing, hunting, travel, and sporting activities. This participant observation provided contextual understanding to develop a better appreciation of perspectives explained in the interviews. Information on climatic exposures and change was obtained from instrumental data collected at the University of Copenhagen's Arctic Station, located in the community. Archival records and secondary sources were also consulted to provide historical context to changes and climatic risks currently experienced, and to identify and characterize how the community has experienced, responded to, and coped with past climatic variability, change, and extremes.

\subsection{Analysis}

Interview transcripts and participant observation notes were transcribed, coded, and analyzed through the use of data analysis software (NVivo, QSR International), in accordance with the principles of latent content analysis and guided by the vulnerability framework. Recurring themes or processes of relevance to the study objectives (such as exposures, sensitivities, and adaptation strategies) were coded and then cross-referenced to identify instances where multiple themes or processes were represented together. Interview data were assessed in conjunction with findings from secondary sources such as government reports, scholarly literature, and climate data. This allowed triangulation of interview narratives with other sources to assess consistency and credibility, and develop a picture of vulnerability and adaptation to changing conditions. Preliminary results were presented, reviewed, and expanded during a dissemination trip and museum display. Anonymous, direct quotes from study participants are used in this article to illustrate responses that typify the study sample.

\section{RESULTS}

\subsection{Current exposure sensitivities}

\subsubsection{Increased feelings of isolation}

It was widely reported by interviewees that 2008 was the only year since 1996 in which sea ice covered Disko Bay to its maximum extent. These findings are consistent with those of Hansen et al. (2006) who document a reduction in annual ice extent of $50 \%$ from 1991 to 2004 in Disko Bay, and with interviews by Holm (2010) in other Disko Bay communities. Variability in ice extent and concentration is historically high in the region, which is located toward the extreme of maximum winter ice extent. For instance, between 1953 and 2001, Stern \& Heide-Jørgensen (2003) report a maximum ice extent in Disko Bay of $13000 \mathrm{~km}^{2}$ in 1955, and $0 \mathrm{~km}^{2}$ in 1962 and 1980, while Holm (2010) reports no ice cover between 1946 and 1947. However, back-to-back years characterized by an absence of permanent ice cover in winter months - experienced between 1996 and 2008, and in 2009, 2010, and 2011 - are unusual and have not been observed previously by local elders or documented in ice data from the Arctic Station (dating back to 1990).

Historically, Qeqertarsuaq was connected to the communities of Ilulissat and Qasigiannguit on the mainland by sea ice trails in winter months. Respondents recollected traveling to these communities by dog sled as recently as 1996 to visit family and friends, for employment, and to exchange goods. With the exception of 2008, such trips have not been possible and a scheduled helicopter service is now the primary transportation option during winter months when the ferry service does not operate. Residents in nearby Kangerluk face more significant challenges, as the settlement's 33 people have no access to scheduled air or ferry service, and yet have to travel to Qeqertarsuaq for the purchase of essential goods such as flour, bullets, fuel, and to collect mail and visit family. The winter sea ice routes are no longer safe and have been replaced by the use of private boats, which is only possible in calm weather and means considerably longer travel time and distance. Access challenges are an additional stress to the settlement where considerable outmigration has accompanied closure of the local fish factory. 
Residents characterized the presence of sea ice as contributing positively to their mental health and sense of well-being, and described increasing feelings of isolation on Disko Island in winter months without access to ice-based trails. Similar observations have been made in isolated Inuit communities in Canada, with access challenges particularly problematic in an Arctic context where ice is not only a transportation medium and hunting platform, but also provides cultural and spiritual 'services' (Eicken et al. 2009). Feelings of isolation have been compounded in recent years by frequent disruption to the scheduled air service. For example, service was cancelled in November 2010 due to strong winds and storm conditions, which were locally described to be partly caused by the lack of ice in Disko Bay. This was followed by a strike at Air Greenland, which cancelled flights for all of December. Food delivery services were unaffected by the strike as they were being provided by boat through Royal Arctic Line AS, but options were limited for individuals trying to leave or return to the community.

\subsubsection{Availability of and access to marine mammals}

Even in years with very low ice coverage in Disko Bay, a narrow platform of landfast ice typically surrounds the community and extends along the coastline. This landfast ice is used for hunting activities that may involve travel by foot, dog sled, or snowmobile, with boats also used in areas where there are ice floes. This ice is essential for harvesting narwhal, walrus, and ringed seal, which are important traditional foods in the community. Ringed seal and walrus are found near old masses of ice with abundant snow drifts. Hunters use sea ice as a platform to hunt both of these animals, yet unstable and dangerous ice conditions were widely reported to be more common by interviewees who regularly hunted. These changes were linked by respondents to the trend in declining winter ice coverage. Ringed seals arrive in the region each year with the formation of ice in November and December and are primarily hunted in April and May when the ice begins to break up and seals can be found sunning themselves on top of the ice floes. They migrate in late May and early June at which time harp seals (aataaq) Phoca groenlandicus return to the area for calving. In storms or windy weather, reported locally to be more frequent in recent years, ringed seals are difficult to hunt as they hide underneath the ice floes. Respondents also described a decrease in the ringed seal population since the 1980s when there were consistent years with strong, stable sea ice conditions. Local observations of declining ringed seal availability are consistent with other studies: Petersen (2004) and Hovelsrud et al. (2008) note that sightings of ringed seals have become increasingly rare in central West Greenland, while historical analysis of seal harvest and air temperature indicates warming temperatures to be associated with declining stocks (Vibe 1967, Rasmussen 2007).

Narwhal are found near the floe edge and need areas of open water (such as leads or cracks in the sea ice) for breathing. While residents have not observed decreases in the availability of narwhal, they noted that narwhal (along with seals) are 'animals of the ice' and expressed fears that continued reductions of sea ice in Disko Bay may harm future populations. As narwhal are found near the floe edge, reductions in sea ice coverage in Disko Bay have led hunters further west and north to recent floe edge locations.

\subsubsection{Increasing availability of cod}

Fishers are intimately familiar with the relationship between climate conditions and fish populations, having experienced the rise and fall of the cod fishery, later replaced by shrimp and snowcrab fisheries, in connection with changing sea temperatures and overfishing. This cod to shrimp/snowcrab transition-described by Hamilton et al. $(2000,2003)$ for western Greenland more generally_resulted in the closure of a factory manufacturing fishing nets in Qeqertarsuaq and the transformation of a shrimp processing factory into a snowcrab factory in 1999. Fishers interviewed in Qeqertarsuaq expressed hope that the warmer air temperatures and lack of sea ice will warm the ocean and encourage the repopulation of cod that were formerly abundant in the area. These hopes are reflected in the development of a cod management plan by the Ministry of Fishing, Hunting, and Agriculture in 2008, in light of the projected return of cod stocks to the west coast with warming water and the anticipated need for sustainable management of the species (Ministry of Fishing Hunting and Agriculture 2008). Some fishers noted an increase in the catch of cod in recent years, and while not currently at commercially exploitable levels, considerable optimism was expressed:

If it continues getting warmer, hunting in the sea won't be affordable. But on the other hand it could be a good thing for fishing. Last year and this year I noticed that the cod (...) are coming back. 
I know that even though we get cold air in winter time, the sea is warmer than normal and that's why we don't have the ice. I know that the sea is warmer because we see our cod coming back now.

Years lacking in sea ice allow fishers to harvest throughout the winter providing they respect fishing regulations and season dates imposed by the Home Rule Government (HRG). Expansion of the snowcrab and shrimp harvesting season, for instance, has resulted from open water winters in Disko Bay. Consequently, the snowcrab processing factory in Qeqertarsuaq has been opening at the beginning of April in recent years, a full month in advance of former operations in years with sea ice. Some respondents expressed fears that advancing the shrimp and snowcrab season will harm the stock due to possible overharvesting, while others remained positive, reporting that snowcrabs in Disko Bay have grown in size in recent years due to temperature changes.

\subsubsection{Increased difficulties for hunters and fishers with small boats}

Although winters lacking ice present opportunities for commercial fishers and those with large boats, they do not benefit all. Strong winds and storms that typically accompany open water seasons were described as preventing smaller vessels from taking advantage of these conditions. Larger boats are able to travel safely in diverse weather conditions and are not as easily deterred by the increases in strong winds and storms that were reported as more prevalent in winters with open water. There were 24 registered vessels in Qeqertarsuaq in 2007, of which 8 can be described as dinghies, <10 GRT, another 8 were $<20$ GRT, and 3 vessels were $>121$ GRT and equipped for off-shore fishing (Statistics Greenland 2008). Owners of small boats $<20$ GRT are typically self-employed subsistence hunters or fishers, while larger off-shore boats commonly employ a crew of 4 workers or more, are equipped for overnight voyages, and often have fish processing or freezing facilities on board. Larger vessels require significantly greater capital investment to purchase and operate, though they are also able to pull in far greater quantities of fish. As described by one respondent, a successful fishing season for a self-employed small boat fisher with a licence may gross 50000 Dkr (\$9000 US) while that same fisher with a larger boat $(30 \mathrm{ft}$, employing 4 crew members) can earn $>2000000$ Dkr (\$359000 US) in a successful season. Hunters and fishers with small boats are particularly sensitive to changing climatic conditions, a fact exacerbated by their existing financial vulnerability, and report implications on their winter income due to days lost to bad weather, in addition to safety concerns. Those interviewed in winter 2011 reported subsisting on government transfer payments due to an inability to hunt or fish and thus to supply food to their households and sell in the local market.

It has a very negative impact on us when we don't sail because we need to catch something first if we want to be paid. We are very dependent on the weather.

It's hard. For example, we caught one seal yesterday (14 April 2011) with nets, but before that, the last seal we caught was on 28 of February.

No significant losses were described by commercial fishers due to bad weather, though respondents commonly highlighted financial difficulties stemming from rising fuel costs and described a need for fuel subsidises not presently offered by the HRG.

Historically, relatively calm weather has been experienced in April and May; however, more recently (over the past decade or so), strong winds and storms are being reported to occur throughout the year now. The most prevalent storms and strong winds occur in autumn (October to December), with particular difficulties for the local population in November. Residents anticipate weather conditions to be stormy in autumn, though these conditions have amplified in recent years, stranding boats that are unable to make it into port. These stresses place a significant economic burden on hunters and fishers, particularly occupational hunters and fishers without a secondary source of income.

\subsubsection{Increased hazards and safety concerns when traveling}

Respondents described a change in predominant wind directions from east and southeast to south, and a general lack of ability to predict winds and wind changes in recent years, consistent with Hansen et al. (2006). Unpredictable and sudden changes in wind strength and direction have caused hunters and fishers to return back to the community for fear of being stuck in unsafe conditions. In addition to safety considerations, economic pressures on hunting and fishing livelihoods resulting from significant decreases in safe harvesting days have led some to travel in conditions they would have otherwise avoided. Recent climatic conditions augment existing pressures on hunters and fishers stemming from government reg- 
ulations, quotas, and licence restrictions (see Sections 3.2 and 4) to create a highly stressful and challenging context in which hunters and small fishers are struggling to earn a living. Economic stresses stemming from the combination of these factors have prevented some from fixing damaged equipment, or updating outdated safety gear for travel.

I would be buying more safety equipment if I had the money, and a bigger boat. I would also definitely become a full time hunter again if I could afford it.

Unpredictably thin sea ice was described as having led to accidents where snowmobiles have fallen through the ice. Snow can blanket seemingly stable ice making it difficult for travelers to accurately foresee hazards. The risks posed by unstable ice conditions are amplified by the use of snowmobiles as traveling speeds are faster and users do not have the benefit of their dogs to help identify and avert problem areas, mirroring observations made in the Canadian Arctic (Krupnik \& Jolly 2002, Ford et al. 2010b, Pearce et al. 2010b)

It is far more dangerous with the snowmobile because you move faster and when you drive dog sleds then you can feel if the ice is moving up or down. When the ice is too thin the dogs usually notice so you can stop and just go back.

The increasing use of snowmobiles has been encouraged by the prevalence of winters lacking sea ice as dog teams are difficult to maintain without strong sea ice where owners can run their dogs. Weather conditions affecting the ability of hunters and fishers to successfully hunt and harvest Greenlandic foods equally prevent the procurement of dog food. Dog teams are typically fed by-catch and unused portions of meats harvested for human consumption such as seal organs. Imported dog food can be purchased at the store, though respondents noted that these foods are unaffordable and do not provide the same energy value as hunted and harvested dog foods.

\subsubsection{Greater difficulty accessing Greenlandic foods}

Difficulties hunting and fishing in recent years were reported to have diminished the supply of wild meats entering the community with subsequent rises in the cost of purchasing Greenlandic foods at open air markets (kalaalimineerniarfik) where traditional foods are sold. Reductions in supply also limit the quantity of food shared in the community outside of the market system. Diminished access to Greenlandic foods challenges food security and has compounded socio-cultural factors changing dietary consumption patterns towards an increased reliance on imported, store-bought foods (Bjerregaard et al. 2001, Goldhar \& Ford 2010, Goldhar et al. 2010).

Today it is very difficult to get seal. I am not hunting as much as before. I buy whale meat sometimes but I miss seal. Seal is the best energy. I miss my older lifestyle. When my youngest son shares Greenlandic foods with me sometimes I give him money because I know it's hard for him to be a hunter. Even though he doesn't want to receive any money from me, I give it to him.

\subsection{Adaptive capacity}

\subsubsection{Hunting/fishing flexibility and diversity}

In an effort to avoid hazardous weather conditions in Disko Bay, fishers are applying for licences further north in the Upernavik area or to the south near Sisimiut. Current fishing licences and quotas are regionally specific however; the most common licences held in Qeqertarsuaq are limited to Disko Bay. The spatial limitations imposed on licences restrict the mobility of fishers who wish to take advantage of favourable conditions in neighbouring districts. Some respondents described failed attempts to gain licences in northern or southern districts for time periods that coincide with stormy weather in Disko Bay.

When it's windy in October and November we could be fishing in other places if we were allowed. We could be fishing for halibut south of here for those 2 months. I have applied to the government for a licence to fish for halibut for those 2 months but I was denied.

Movement outside the municipality to fish requires additional fuel and larger boats suited to overnight travel on the open sea, thereby necessitating additional cost. Respondents characterized fishing conditions in the Upernavik area as attractive, though residents with licences for this district noted significant iceberg hazards in recent years. Large icebergs can prevent safe passage to fishing grounds: they disrupted fishing near Upernavik for 5 consecutive days in 2008. While some fishers are seeking fishing licences for municipalities outside of Qaasuitsup, some with existing licenses in distant regions are attempting to gain licences closer to home in an attempt to ameliorate rising fuel and travel costs. Respondents report that many of these applications have been rejected as Qaasuitsup is currently reducing the number of small vessel fishing licences held 
in the region with an intention of eliminating 200 licences from the current 600 that are administered.

In response to reductions in seal sightings in Disko Bay, hunters described following the seals as they move further north to areas with abundant sea ice in winter months. A similar practice was described for hunting walrus and narwhal, which are commonly available near the floe edge or near old masses of ice. During ice-free winters in Disko Bay, hunters travel further west and north to the flow edge of the 'great ice' (also known as the 'west ice' or vestisen) located north of Davis Strait in Baffin Bay between West Greenland and Canada.

Hunters and fishers are also reflecting on each year's experiences, considering the challenges posed by weather conditions and other factors, and adjusting hunting and fishing methods and travel strategies in response. Respondents from Kangerluk described a preference for traveling in groups to Qeqertarsuaq and pooling safety gear such as geographical positioning systems (GPSs), very high frequency (VHF) radios, and other resources to best reduce risk from potentially hazardous conditions. In the hope of maximizing potential sales of their catch, hunters from Qeqertarsuaq noted concentrating hunting trips at the end of each month to coincide with a period in which many residents receive social transfer payments. Hunters and fishers also described critically evaluating risks posed by weather conditions each day in conjunction with the economic benefits of possible catch when deciding whether or not to travel, carrying VHF radios, cell phones, and GPS's with them in their boats more frequently in case danger is encountered, and notifying other harvesters of hazardous conditions. In this way, coping mechanisms combine both reactive and anticipatory responses, are primarily behavioural in nature, and conducted at a local level.

We don't sail just for seal. It's not affordable to do that anymore and it's not worth traveling in the risky weather.

When we prepare for next year's fishing or hunting, we adapt our equipment or our way of fishing or hunting based on what happened this year. In that way we are changing from what we are experiencing.

Increasing prevalence of delays, sometimes requiring unanticipated overnight stays due to poor weather or strong winds, were described as having motivated hunters to bring additional supplies such as food and fuel and to budget additional time for their travels. Respondents described needing more time to travel in autumn due to the frequency of storms. Reindeer hunting trips in the Sisimuit area to the south that previously took $1 \mathrm{~d}$, for example, have taken up to $4 \mathrm{~d}$ in recent years due to hazardous weather conditions. Many also described a desire to upgrade safety gear and diversify hunting and fishing equipment to better exploit open water winters lacking sea ice, such as through the purchase of larger boats, yet this option is often precluded by the considerable cost involved.

The environmental knowledge and land-skills possessed by many hunters and fishers, along with mobility and diversity in resource use, was described as essential for adaptation. This knowledge allows residents to alter harvesting practices and utilize new areas, thus minimizing potential safety considerations in connection with changing wind and ice conditions. With broad knowledge of animal populations and general environmental characteristics of the area, hunters and fishers are able to substitute the harvest of unavailable animals for more abundant alternatives-where regulations allow. They are also able to adjust the timing and location of their harvesting to best take advantage of favourable conditions.

\subsubsection{Role of women as wage earners}

Respondents noted that the transitioning role of women in Greenlandic society, and in Qeqertarsuaq in particular, from the historic role of a 'hunter's wife' to that of a waged worker has moderated recent economic stresses experienced by occupational hunters in-light of changing climatic conditions. This is in part because income restrictions imposed by the HRG prevent occupational hunters and fishers from attaining paid jobs outside of their primary livelihoods. Consequently, they are unable to supplement their hunting and fishing income with secondary employment while simultaneously maintaining their full-time hunting or fishing licence (and hunting rights this accrues). While some women noted seeking waged work to support their partner in response to recent stresses, the majority were already working as changing climatic conditions have become increasingly pronounced. This transition thus constitutes an adaptive strategy for some, while the majority of women were gradually joining the employment sector due to factors independent of changing economic and environmental conditions. Broad, socioeconomic changes in Greenland have been analyzed in association with this demographic trend by Hamilton et al. (1996) and Hamilton \& Rasmussen (2010). While women in Qeqertarsuaq reported gaining jobs in the community and supporting the hunting and 
fishing livelihoods of their partners, a lack of job opportunities in Greenland has encouraged an outmigration of educated women from other coastal communities (Hamilton et al. 1996, Hamilton \& Rasmussen 2010). Similar trends have been identified in other areas dominated by fishing and other primaryindustry employment such as Alaska and across the North Atlantic (including Newfoundland, Iceland and Norway; Hamilton et al. 1994a,b, Hamilton \& Otterstad 1998) and are not necessarily linked with recently observed environmental changes.

As described by women interviewed in this study, the 'hunter's wife' provided essential contributions to the subsistence economy through the labor of preparing animals skins, making clothing, cooking meals, and otherwise caring for children and the home. While some women described feelings of sadness associated with movement into waged positions and the potential loss of these highly valued and culturally-significant skills, others discussed these changes positively. These respondents emphasized increasing freedom and choice for women in recent years that they associated with education and job opportunities. Working women are able to bring home valuable cash income in hunting and fishing households, sustaining their family and the livelihood of their partner within circumstances that would have otherwise been very difficult. Indeed, the presence of a second income within hunting households was described by some as alleviating economic pressures that may have otherwise encouraged hunters to travel in unsafe conditions.

Today's hunting is possible because of the women. My mother has been working since she was very young. She has a husband that hunts and if she didn't work they wouldn't have much to live for.

I'm one of the lucky ones because my wife has a job. So I don't have to risk my life to try to hunt on bad days.

Hunters also described feelings of guilt and regret after an unsuccessful hunting or fishing trip knowing that their partner is working to cover the costs of their livelihood.

The strong winds have a negative impact on us because in winter there is no ice but we cannot sail. I feel sorry for my wife because she has to work to pay the gasoline for the boat. When I come home and have nothing to give back I feel sorry.

\subsubsection{Livelihood diversity}

In addition to the significant financial contributions made by women to the household, some occupational hunters described attaining a non-occupational license that allows them to earn income from a waged job outside of hunting and fishing. Income from what was described as a 'land job' was thought to be increasingly necessary to afford to continue hunting and fishing in-light of the need for new equipment (e.g. larger boats, satellite phone, GPS) and reduced opportunities to harvest, especially for those without an income-earning partner. While a seemingly attractive adaptation to recent hunting and fishing pressures, transitioning from an occupational to a non-occupational hunter or fisher requires the acceptance of additional restrictions governing the catch and sale of available species. Non-occupational hunters are not allowed to hunt polar bear, walrus, bowhead whale, fin whale, or minke whale, and subsistence fishers are not permitted to sell their catch (Statistics Greenland 2010). These regulations limit the possible income earned through non-occupational hunting and fishing and have been a significant source of conflict within the community and across Greenland (see for example: Sejersen 2001). They also discourage occupational hunters from seeking secondary sources of employment as these changes would necessitate attaining a non-occupational licence.

This transition is additionally difficult because of the economic investment many hunters have made in equipment (such as large harpoon guns) needed for the harvest of large mammals that are only available to occupational licence holders. This equipment is expensive and increasingly difficult to sell as occupational hunting and fishing livelihoods become more challenging. Respondents who have exchanged occupational licences for non-occupational licenses and taken land-jobs typically characterized this transition as an undesirable change resulting from economic necessity. Hunters and fishers described a strong preference for working outside and the 'independence' that hunting and fishing livelihoods offer.

I don't want to get a job because as a fisher and hunter you have more independence. You decide when you want to go hunting. I don't want to be managed by other people. I was raised as a hunter and fisher so for me it's difficult to just work on the land and not sail and hunt for seals.

It's harder to be a fisher and hunter than to be a carpenter but I have chosen to fish because I have more freedom. I like to have more freedom. Sometimes people call and ask if I want to work for them but I just say no. I prefer to be a fisher.

Some have begun working in the tourism sector, leading dogsled tours on the nearby Lyngemark glacier. The seasonal nature of tourism is desirable for 
those who wish to remain active in their hunting and fishing livelihoods, and provides a regular opportunity to run your sled dogs in summer months. However, these positions are few in number and require English or Danish language skills that hunters and fishers do not always have. Indeed, despite the overall economic health and employment opportunities in Qeqertarsuaq, hunters and fishers often do not have the requisite skills and training, making it additionally difficult for them to supplement income with secondary employment.

In recent years I have been concentrating on tourism. That was because of the lack of the ice. I needed to find another way of make money.

Finding a job would not be easy for me because I only have a drivers license and radio license-I don't have an education. I left school early to join my father and uncle on their fishing boat. I'm thinking about maybe working with tourists in the future as a part time job but my English is not very good. It's not easy to get a job here in Qeqertarsuaq.

\subsubsection{Government regulations}

Hunting and fishing regulations and harvesting quotas were consistently identified as constraining adaptive capacity. Full-time hunters and fishers expressed frustration regarding income restrictions that currently limit their ability to find part-time waged work. Respondents also drew attention to the role of hunting and fishing regulations in limiting their ability to adapt harvesting practices in response to recent changes. They highlighted the unnecessarily restrictive nature of regulations such as quotas, season dates, and harvest locations, claiming they are unreflective of recent environmental changes and uninformed by the local knowledge of hunters and fishers. Narwhal quotas, in particular, were commonly described as unnecessarily limiting their harvest. Regulation pressures on the hunt of narwhal, combined with the high economic and cultural value of the species, has led to conflict between occupational and non-occupational hunters and their representative unions. Kalaallit Nunaanni Aalisartut Piniartullu Kattuffiat (KNAPK, the Organization of Hunters and Fishers in Greenland, representing the interests of occupational hunters) has been lobbying the HRG to modify the narwhal quota so it is solely available to occupational hunters, rather than both occupational and non-occupational hunters as it was at the time of this publication.

The capacity of residents to adapt to economic pressures on hunting and fishing livelihoods and changing climatic conditions is directly related to the diversity of options available to them. While regulations arguably protect the future health of harvested species and prevent over-exploitation, they also limit the mobility and flexibility of harvesting that historically enabled communities to manage environmental change. The licensing system was established in 1995, and fosters harvesting behaviour in contrast to the historic system where communities were able to modify target species, harvest dates, and hunting locations in accordance with shifts in animal migration patterns, guided by local custom and traditional knowledge (see for example: Hastrup 2009).

I just hope that we will get some help from the government because they are kind of taking our money away by the regulations. They should give something back. When the quota is over we cannot hunt any more even though there are lots of animals that can be hunted. We can't go to the municipality and ask for money even though we have nothing to live for.

\section{DISCUSSION}

This work contributes to an expanding scholarship on HDCC in the Arctic, and can help broaden our understanding of how global change is playing out in local places. Comparing the findings with research from other Arctic regions in general and Inuit populations in particular, a number of key conclusions can be drawn concerning the vulnerability and adaptive capacity of small subsistence based hunting/fishing communities.

Firstly, communities are not powerless victims in the face of climate change, and adapt in numerous ways. This may involve taking advantage of new opportunities, such as fishers with large boats in this study or the local snowcrab factory which has been able to extend its season of operation with reduced sea ice cover. For others, adaptations involve behavioural modifications such as changing the location, timing, and species harvested; managing risks through the use of new equipment; and acceptance of risk. Such flexibility is based on environmental knowledge and land skills, and has evolved in the context of historic climatic variability. These findings mirror similar responses to climate change among Canada's Inuit population (Wenzel 2009, Ford \& Pearce 2010, Ford et al. 2010b, Pearce et al. 2010a), Sami reindeer herders in Scandinavia (Tyler et al. 2007), and Alaska natives (Krupnik \& Ray 2007, Huntington et al. 2009, Rattenbury et al. 2009, Huntington 2011).

Secondly, the ability to adapt is not equal, may result in the emergence of winners and losers, and 
engender socio-economic trade-offs that are undesirable. Livelihood diversity for example, may enable former occupational hunters in Qeqertarsuaq to maintain some aspects of their subsistence livelihood at the expense of full engagement in hunting activities due to the regulated nature of harvesting. In other areas, regulations determine who is able to adapt and how, resulting in conflict between occupational and non-occupational hunters. Access to income is particularly important, and the ability to purchase new safety equipment and large boats are important adaptations available to those with access to cash resources. While not as problematic in Qeqertarsuaq due to its strong wage economy relative to the Canadian Inuit context (e.g. Furgal \& Seguin 2006, Furgal \& Prowse 2009, Ford et al. 2010b), those engaged in hunting livelihoods are limited in their ability to earn income due to harvesting regulations, and typically lack the formal training and language skills necessary for waged employment. For such individuals, having a partner who earns a wage is important in assisting household adaptation.

Thirdly, the pathways through which climate change affects local livelihoods are rarely direct, and are typically mediated by socio-economic conditions and processes that are also changing. These non-climatic stresses vary among groups, households, and individuals at the community level, and may exacerbate or moderate vulnerability depending on the local context. Some of the key trends increasing sensitivity and constraining adaptive capacity documented in Qeqertarsuaq, for example, differ quite considerably from Inuit communities in North America that are undergoing similar changes in climate. In Canada for instance, an erosion of land skills among younger Inuit has been identified in numerous studies as exacerbating vulnerability to climate change, but was not mentioned here (despite specific questions to this end) and results in less pronounced danger-related vulnerabilities for youth in Qeqertarsuaq. This likely reflects the population profile of Qeqertarsuaq with many youth leaving the community for education on the mainland or entering full-time waged employment, the regulated nature of hunting and fishing that limits the participation of non-professional harvesters, and less dependence on sea ice environments necessitated by contemporary harvesting activities in the region. Constraints on the mobility and flexibility of harvesters to respond to changing conditions imposed by regulations, however, are significant in Greenland and constrain adaptive capacity by affecting who can hunt/fish what, where, how, and when. While regulations have also been identified as barriers to adaptation in a Canadian Inuit context and more broadly with regards to Arctic resource management (Armitage 2005, Ford et al. 2006a,b, Beaumier \& Ford 2010, Hovelsrud \& Smit 2010, Dale \& Armitage 2011, Keskitalo et al. 2011), the trend towards co-management of wildlife resources in North America is less evident in Greenland, where resource management remains highly centralized (Cuyler 2007, Nuttall 2009).

Fourthly, non-climatic stresses affecting vulnerability and adaptation need to be understood in a broader spatial-temporal context. The establishment of Greenlandic Home Rule in 1979 has resulted in significant political and socio-economic change, creating new contexts that hunters and fishers have had to respond to. One consequence has been the consolidation of Nuuk as the administrative and political centre of Greenland, with decision making-including resource management-centralized at this level. This provides context for some of the emerging vulnerabilities to climate change in the subsistence economy documented here. Thus, the development of nationwide harvesting regulations has overruled local customs and control over harvesting, and elevated the role of biologists and international/regional management commissions in setting quotas and access rights with limited integration of local knowledge (Sejersen 2001, Cuyler 2007, Nuttall 2009). This has limited local diversity and flexibility to respond to changing conditions. Prior to regulations, access was based on social control of community hunting territory and defined by the social obligation to accept the local customs on hunting methods, division, and sharing, evolving in light of local social and biophysical conditions (Dahl 2000, Sejersen 2001). Hunters were therefore traditionally able to harvest in other regions providing they respected local customs, in contrast to today's regulations, which impose geographic limits as evident in the limited ability of Qeqertarsuaq fishers to travel to safer locations. Sejersen (2001) has also described how regulations have contributed to the erosion of the moral economy of harvesting, reflecting the compartmentalization of social groups with different access rights. Particularly in light of stresses imposed by a changing climate and reductions in harvest quotas in response to scientific concerns over stock size, the differential access rights of occupational and non-occupational hunters have resulted in conflict and a weakening of social relations at a community level; both widely recognized in the general scholarship as important components of adaptive capacity (Adger 2001, Adger et al. 2009) 
Another consequence of Home Rule has been the promotion of industrial development as a centrepiece of nation building, with the ultimate aim of achieving full independence from Denmark (Nuttall 2008, 2009, Sejersen 2009). This is reflected in the HRGs position on climate change where the economic benefits (mining, oil and gas) of changing ice regimes and melting of the ice cap have been widely promoted. In this framing, the larger scale benefits of climate change outweigh the negative implications for small resource-based settlements, reinforcing the HRGs focus on economic development (Nuttall 2008). It is also reflected in the limited attention in the political arena towards examining how the negative effects of climate change for the smaller more northerly settlements can be moderated. Indeed, the future of small settlements has long been debated in Greenland, with policy encouraging depopulation of smaller settlements and investments largely channelled to major centres with their economic functions. This contrasts the Canadian north where adaptation has become a major focus of climate policy both federally and territorially, and where concerns about the impact of climate change on small subsistence-based communities have been an important line of inquiry (Ford et al. 2010b, 2011).

\section{CONCLUSION}

This paper reports on one of the first case studies focusing on identifying and examining vulnerability to climate change at a community-level in Greenland. As such, the work develops a baseline understanding of the risks posed, coping mechanisms being employed, and determinants of adaptive capacity. Focusing on the subsistence economy of Qeqertarsuaq, the research highlights that changing climatic conditions on the one hand are constraining access and availability of key wildlife resources and exacerbating the dangers of hunting and fishing, while also creating new opportunities. While Qeqertarsuaq hunters and fishers are highly adaptable to a changing climate, the centralizing tendencies associated with Home Rule have (1) reduced flexibility and diversity in resource use that has traditionally underpinned adaptation, (2) contributed towards the emergence of conflict over resource use as local customs have been overruled, and (3) resulted in limited attention to small subsistence orientated communities in climate change policy discourse. These slow variables provide the context within which climate change is and will be experienced.
While adaptation has not received widespread attention at a policy level in Greenland, in Qeqertarsuaq people are autonomously adapting through behavioural responses, drawing upon their accumulated knowledge and experience of environmental conditions. Yet these adaptations are constrained by national level factors outside local control and with long historical antecedents. Therefore, while community-based responses and adaptation planning can be important in preparing for climate change, on their own they are likely not enough. Specifically, harvesting regulations are a barrier to adaptation, and while we do not dispute the need for some regulation in a contemporary setting, the nature of regulations should be revisited in light of climate change projections. Scholarship on wildlife co-management offers a number of potential models that could be explored herein (Chapin et al. 2004, Berkes 2007, Berkes et al. 2007, Dale \& Armitage 2011). Adaptation will also require forward-looking investment both to address future risks (and opportunities) and to more effectively deal with current risks. Many adaptations are costly and exceed the financial capability of individuals and households, both in terms of new harvesting equipment required and the economic costs for occupational hunters of not being able to access fish or animals. Emergency funds are currently offered through the HRG, and while important, community members frequently reported the lack of support available at a national level for the harvesting sector.

In advancing the research and policy agenda on adaptation, it is important that communities, policy makers, scientists, and other stakeholders are actively involved in identifying and examining adaptation needs. This has not yet happened in Greenland, and will require national recognition of the challenges posed by climate change to small subsistence based settlements. In addition, there is a need for state institutions to broaden their framing of the climate change issue - beyond the largly technical perspective, focused at the national level, that currently exists - to encompass local knowledge. Ultimately however, the success of adaptation will depend upon the extent to which culturally important subsistence activities of predominantly small communities are valued within the political discourse of nation building in Greenland.

Acknowledgements. This research was supported by the CAVIAR International Polar Year project and the Social Sciences and Humanities Research Council of Canada (SSHRC). The work was conducted under a McGill certifi- 
cate of ethical acceptability of research involving human subjects REB\#: 345-0508. In Qeqertarsuaq we thank L. Grønvold, U. Grønvold, A. Dahl, L. Berthelsen, and Arctic Station of the University of Copenhagen. We also thank B. Smit for valuable insight to our work, L. Berrang Ford, and P. Adams for help with manuscript preparation.

\section{LITERATURE CITED}

ACIA (2005) Arctic Climate Impacts Assessment. ACIA Scientific report, Cambridge University Press, Cambridge

Adger WN (2001) Social capital and climate change. Tyndall Centre for Climate Change, Norwich

Adger N, Dessai S, Goulden M, Hulme M and others (2009) Are there social limits to adaptation to climate change? Clim Change 93:335-354

Armitage DR (2005) Community-based narwhal management in Nunavut, Canada: change, uncertainty, and adaptation. Soc Nat Resour 18:715-731

Arnason R (2007) Climate change and fisheries: assessing the economic impact in Iceland and Greenland. Nat Resour Model 20:163-197

> Beaumier M, Ford J (2010) Food insecurity among Inuit females exacerbated by socio-economic stresses and climate change. Can J Public Health 101:196-201

> Berkes F (2007) Understanding uncertainty and reducing vulnerability: lessons from resilience thinking. Nat Hazards 41:283-295

Berkes F, Berkes MK, Fast H (2007) Collaborative integrated management in Canada's north: the role of local and traditional knowledge and community-based monitoring. Coast Manag 35:143-162

Box JE, Yang L, Bromwich DH, Bai LS (2009) Greenland ice sheet surface air temperature variability: 1840-2007. J Clim 22:4029-4049

Burton I, Lim B (2005) Adaptation policy framework for climate change. Cambridge University Press, Cambridge

> Chapin FS, Peterson G, Berkes F, Callaghan TV and others (2004) Resilience and vulnerability of northern regions to social and environmental change. Ambio 33:344-349

Chylek P, Dubey MK, Lesins G (2006) Greenland warming of 1920-1930 and 1995-2005. Geophys Res Lett 33: L11707, doi:10.1029/2006GL026510

Collings P (2009) Participant observation and phased assertion as research strategies in the Canadian Arctic. Field Methods 21:133-153

Collings P (2011) Economic strategies, community, and food networks in Ulukhaktok, Northwest Territories, Canada. Arctic 64:207-219

Comiso JC (2003) Warming trends in the Arctic from clear sky satellite observations. J Clim 16:3498-3510

Cuyler C (2007) West Greenland caribou explosion: What happened? What about the future? Proc 11th N Am Caribou Workshop, Jasper, Alberta, 23-27 April 2006. Rangifer 17:219-226

Dahl J (2000) Saqqaq: an Inuit hunting community in the modern world. University of Toronto Press, Toronto

> Dale A, Armitage D (2011) Marine mammal co-management in Canada's Arctic: knowledge co-production for learning and adaptive capacity. Mar Policy 35:440-449

Drinkwater KF (2005) The response of Atlantic cod (Gadus morhua) to future climate change. J Mar Sci 62: 1327-1337

Duerden F (2004) Translating climate change impacts at the community level. Arctic 57:204-212
Dugmore AJ, Keller C, McGovern TH (2007) Norse Greenland settlement: reflections on climate change, trade, and the contrasting fates of human settlements in the North Atlantic islands. Arctic Anthropol 44:12-36

Eicken H, Lovecraft A, Druckenmiller ML (2009) Sea ice system services: a framework to help identify and meet information needs relevant for Arctic observing networks. Arctic 62:119-136

$>$ Ford JD, Furgal C (2009) Foreword to the special issue: climate change impacts, adaptation and vulnerability in the Arctic. Polar Res 28:1-9

Ford JD, Pearce T (2010) What we know, do not know, and need to know about climate change vulnerability in the western Canadian Arctic: a systematic literature review. Environ Res Lett 5:014008, doi:10.1088/1748-9326/5/1/ 014008

Ford J, Pearce T (2012) Climate change vulnerability and adaptation research focusing on the Inuit subsistence sector in Canada: directions for future research. Can Geogr 56(2):275-287

Ford J, Smit B (2004) A framework for assessing the vulnerability of communities in the Canadian Arctic to risks associated with climate change. Arctic 57:389-400

Ford JD, Smit B, Wandel J (2006a) Vulnerability to climate change in the Arctic: a case study from Arctic Bay, Canada. Glob Environ Change 16:145-160

Ford JD, Smit B, Wandel J, MacDonald J (2006b) Vulnerability to climate change in Igloolik, Nunavut: What we can learn from the past and present. Polar Rec (Gr Brit) 42: $127-138$

Ford J, Keskitalo ECH, Smith T, Pearce T, Berrang-Ford L, Duerden F, Smit B (2010a) Case study and analogue methodologies in climate change vulnerability research. WIREs Clim Change 1:374-392

> Ford JD, Pearce T, Duerden F, Furgal C, Smit B (2010b) Climate change policy responses for Canada's Inuit population: the importance of and opportunities for adaptation. Glob Environ Change 20:177-191

Ford JD, Smith T, Berrang-Ford L (2011) Canadian federal support for climate change and health research compared with the risks posed. Am J Public Health 101(5): 814-821

> Furgal C, Prowse T (2009) Climate impacts on northern Canada: introduction. Ambio 38:246-247

> Furgal CM, Seguin J (2006) Climate change, health and community adaptive capacity: lessons from the Canadian north. Environ Health Perspect 114:1964-1970

Fussel HM, Klein RTJ (2006) Climate change vulnerability assessments: an evolution of conceptual thinking. Glob Environ Change 75:301-329

Goldhar C, Ford J (2010) Climate change vulnerability and food security in Qeqertarsuaq, Greenland. In: Hovelsrud G, Smit B (eds) Community adaptation and vulnerability in Arctic regions. Springer, Dordrecht

> Goldhar C, Ford J, Berrang-Ford L (2010) Prevalence of food insecurity in a Greenlandic community and importance of social-economic-environmental stressors. Int J Circumpolar Health 69:285-303

Hamilton LC, Otterstad O (1998) Sex ratio and community size: notes from the Northern Atlantic. Popul Environ 20: $11-22$

Hamilton LC, Rasmussen RO (2010) Population, sex rations and development in Greenland. Arctic 63:43-52

Hamilton LC, Lawrence C, Seyfrit CL (1994a) Coming out of the country: community size and gender balance among 
Alaskan Natives. Arctic Anthropol 31:16-25

Hamilton LC, Lawrence C, Seyfrit CL (1994b) Female flight? Gender balance and outmigration by Native Alaskan villagers. Arctic Med Res 53(Suppl 2):189-193

Hamilton LC, Rasmussen RO, Flanders NE, Seyfrit CL (1996) Outmigration and gender balance in Greenland. Arctic Anthropol 33:89-97

- Hamilton L, Lyster PA, Otterstad O (2000) Social change, ecology and climate in 20th century Greenland. Clim Change 47:193-211

Hamilton LC, Brown BC, Rasmussen RO (2003) West Greenland's cod-to-shrimp transition: local dimensions of climatic change. Arctic 56:271-282

Hansen AS, Nielsen TG, Levinsen H, Madsen SD, Thingstad TF, Hansen BW (2003) Impact of changing ice cover on pelagic productivity and food web structure in Disko Bay, West Greenland: a dynamic model approach. DeepSea Res I 50:171-187

Hansen BU, Elberling B, Humlum O, Nielsen N (2006) Meteorological trends (1991-2004) at Arctic Station, Central West Greenland $\left(69^{\circ} 15^{\prime} \mathrm{N}\right)$ in a 130 years perspective. Geografisk Tidsskrift, Danish J Geogr 106:45-55

Hastrup K (2009) The nomadic landscape: people in a changing arctic environment. Geografisk Tidsskrift, Danish J Geogr 109:181-189

Holm LK (2010) Sila-Inuk: study of the impacts of climate change in Greenland. In: Krupnik I, Aporta C, Gearheard S, Laidler GJ, Holm LK (eds) SIKU: knowing our ice. Springer Dordrecht, p 145-160

Hovelsrud G, Smit B (eds) (2010) Community adaptation and vulnerability in Arctic regions. Springer, Dordrecht

> Hovelsrud GK, McKenna M, Huntington H (2008) Marine mammal harvests and other interactions with humans. Ecol Appl 18:S135-S147

Huntington HP (2011) Arctic science: the local perspective. Nature 478:182-183

- Huntington H, Hamilton L, Nicholson C, Brunner R, Lynch A, Ogilvie AEJ, Voinov A (2007) Toward understanding the human dimensions of the rapidly changing arctic system: insights and approaches from 5 HARC projects. Reg Environ Change 7:173-186

> Huntington HP, Kruse SA, Scholz AJ (2009) Demographic and environmental conditions are uncoupled in the social-ecological system of the Pribilof Islands. Polar Res 28:119-128

IPCC (2007) Climate change 2007: the physical science basis. Contribution of Working Group I to the Fourth Assessment Report of the Intergovernmental Panel on Climate Change. Cambridge University Press, Cambridge

> Johannessen OM, Miles MW (2011) Critical vulnerability of marine and sea ice-based ecosystems in the high Arctic. Reg Environ Change 11(Suppl. 1):239-248

Keskitalo EC (2008) Climate change and globalization in the Arctic: an integrated approach to vulnerability assessment. Earthscan, London

Keskitalo ECH, Dannevig H, Hovelsrud GK, West JJ, Swartling AG (2011) Adaptive capacity determinants in developed states: examples from the Nordic countries and Russia. Reg Environ Change 11:579-592

Krupnik I, Jolly D (2002) The Earth is faster now: indigenous observations of climate change. ARCUS, Fairbanks, AK

Krupnik I, Ray GC (2007) Pacific walruses, indigenous hunters, and climate change: bridging scientific and indigenous knowledge. Deep-Sea Res II 54:2946-2957

Malone EL, Engle NL (2011) Evaluating regional vulnerabil- ity to climate change: purposes and methods. WIREs Clim Change 2:462-474

Ministry of Fishing Hunting and Agriculture (2008) Summary of Greenland cod management plan, available at: http://uk.nanoq.gl/Emner/Government/Departments/ ministry_of_fisheries/Fisheries \%20unit/Management\% 20plans.aspx

Nuttall M (2008) Climate change and the warming politics of autonomy in Greenland. Indigenous Affairs 1-2:44-51

Nuttall M (2009) Living in a world of movement: human resilience to environmental instability in Greenland. In: Crate S, Nuttall M (eds) Anthropology and climate change. Left Coast Press, Walnut Creek, CA, p 292-310

O'Brien K, Eriksen S, Nygaard LP, Schjolden A (2007) Why different interpretations of vulnerability matter in climate change discourses. Clim Policy 7:73-88

Pars T, Osler M, Bjerregaard P (2001) Contemporary use of traditional and imported food among Greenlandic Inuit. Arctic 54:22-31

Pearce T (2011) Transmission of environmental knowledge and land skills and adaptation to climate change in the Arctic. PhD thesis, University of Guelph

Pearce TD, Ford JD, Laidler GJ, Smit B and others (2009) Community collaboration and climate change research in the Canadian Arctic. Polar Res 28:10-27

Pearce T, Ford J, Duerden F, Smit B, Andrachuk M, Berrang-Ford L, Smith T (2010a) Advancing adaptation planning for climate change in the Inuvialuit Settlement Region (ISR): a review and critique. Reg Environ Change 11:1-17

Pearce T, Smit B, Duerden F, Ford J and others (2010b) Inuit vulnerability and adaptive capacity to climate change in Ulukhaktok, Northwest Territories, Canada. Polar Rec (Gr Brit) 24:1-21

Petersen J (2004) Greenland. In: North Atlantic Marine Mammal Commission (ed) Proc NAMMCO workshop on hunting methods for seal and walrus, 7-9 Sept, Copenhagen, p 15-16

Poppel B, Kruse J, Duhaime G, Abryutina L (2007) SLiCA Results. In. Institute of Social and Economic Research, University of Alaska Anchorage, Anchorage, AK

Qaasuitsup Municipality (2010) Facts about the municipality, available at: www.qaasuitsup.gl/en/Om-kommunen/ Fakta-om-kommunen (accessed 27 Nov 2011)

Rasmussen RO (2007) Adjustment to reality: social responses to climate changes in Greenland. In: Ørbaek JB, Kallenborn R, Tombre I, Hegseth EN, Falk-Petersen S, Hoel AH (eds) Arctic and alpine ecosystems and people in a changing environment. Springer, Berlin, p 167-180

Rattenbury K, Kielland K, Finstad G, Schneider W (2009) A reindeer herder's perspective on caribou, weather and socio-economic change on the Seward Peninsula, Alaska. Polar Res 28:71-88

Sejersen F (2001) Hunting and management of beluga whales (Delphinapterus leucas) in Greenland: Changing strategies to cope with new national and local interests. Arctic 54:431-443

Sejersen F (2009) Resilience, human agency and climate change adaptation strategies in the Arctic. In: Hastrup K (ed) The question of resilience: social responses to climate change. RDASL, Copenhagen, p 218-244

Smit B, Pilifosova O (2003) From adaptation to adaptive capacity and vulnerability reduction. In: Smith J, Klein RTJ, Huq S (eds) Climate change, adaptive capacity, and development. Imperial College Press, London 
Smit B, Wandel J (2006) Adaptation, adaptive capacity and vulnerability. Glob Environ Change 16:282-292

Smit B, Burton B, Klein RJT, Wandel J (2000) An anatomy of adaptation to climate change and variability. Clim Change 45:223-251

Sorensen M (2010) Inuit landscape use and responses to climate change in the Wollaston Forland-Clavering $O$ region, Northeast Greenland. Geografisk Tidsskrift. Danish J Geogr 110:155-174

Statistics Greenland (2008) Vessels by district, available at: www.stat.gl/dialog/main.asp?lang=en\&version=2010\&link $=$ FI\&subthemecode $=t 6 \&$ colcode $=t$ (accessed 28 Nov 2011)

Statistics Greenland (2010) Administration of catching and hunting. www.stat.gl (accessed 19 Sep 2011) (in Greenlandic)

Stern HL, Heide-Jørgensen MP (2003) Trends and variability of sea ice in Baffin Bay and Davis Strait, 1953-2001. Polar Res 22:11-18

Turner B, Kasperson RE, Matson PA, McCarthy J and others (2003a) A framework for vulnerability analysis in sustainability science. PNAS 100:8074-8079

Turner BL, Matson PM, McCarthy JJ, Corell RW and others (2003b) Illustrating the coupled human-environment sys-

Editorial responsibility: Nils Chr. Stenseth, Oslo, Norway tem for vulnerability analysis: three case studies. PNAS 100:8080-8085

Tyler NJC, Turi JM, Sundset MA, Bull KS and others (2007) Saami reindeer pastoralism under climate change: applying a generalized framework for vulnerability studies to a sub-arctic social-ecological system. Glob Environ Change 17:191-206

Van Voorst R (2009) 'He just waits for the animals to come back'. Social impacts of climate changes: a Greenlandic case study. JAMBA: Journal of Disaster Risk Studies 2: $235-252$

Vibe C (1967) Arctic animals in relation to climate fluctuations. CA Reitzels Forlag, Copenhagen

Wenzel G (2009) Canadian Inuit subsistence and ecological instability: if the climate changes, must the Inuit? Polar Res 28:89-99

> Westerhoff L, Smit B (2009) The rains are disappointing us: dynamic vulnerability and adaptation to multiple stressors in the Afram Plains, Ghana. Mitig Adapt Strateg Glob Change 14:317-337

Wieland K (2004) Length at sex transition in northern shrimp (Pandalus borealis) off west Greenland in relation to changes in temperature and stock size. Fish Res 69:49-56

Submitted: December 15, 2011; Accepted: June 13, 2012 Proofs received from author(s): September 10, 2012 